\title{
PENGARUH STRATEGI PEMBELAJARAN TERHADAP HASIL BELAJAR EKONOMI SISWA MAN KOTA LANGSA PROVINSI ACEH
}

\author{
Oleh:
}

Tarmizi

Guru pada MAN 1 Langsa

\begin{abstract}
ABSTRAK
Tujuan penelitian quasi - eksperimental ini adalah untuk mengetahui : (1) hasil belajar Ekonomi siswa yang diajarkan dengan strategi pembelajaran Ekspositori, (2) hasil belajar Ekonomi siswa dengan kemandirian belajar tinggi dan siswa dengan kemandirian belajar rendah, dan (3) interaksi antara strategi pembelajaran dan hasil belajar Ekonomi siswa. Populasi penelitian adalah para siswa MAN Kp. Teungoh. Berdasarkan teknik cluster random sampling sampel yang terpilih untuk kelas yang diajarkan dengan strategi strategi pembelajaran Ekspositori adalah siswa Kelas XI - 1 MAN Kp. Teungoh dengan 40 siswa. Data dianalisis dengan, ANAVA 2 jalur pada tingkat signifikansi $\alpha=0,05$ yang dilanjutkan dengan uji Scheffe. Hasil penelitian adalah: (1) nilai rata - rata hasil belajar Ekonomi siswa yang diajarkan dengan menggunakan strategi pembelajaran Ekspositori adalah $\bar{X}=$ 26, 92 dengan $F_{\text {hitung }}=29,57>F_{\text {tabel }}=3,968$ (2) nilai rata - rata hasil belajar Ekonomi siswa dengan kemandirian belajar rendah adalah $\bar{X}=26$, dengan $F_{\text {hitung }}=4,43>\mathrm{F}_{\text {tabel }}=3,968$, dan (3) terdapat interaksi antara strategi pembelajaran dan kemandirian belajar terhadap hasil belajar Ekonomi siswa dengan $F_{\text {hitung }}=7,18>\mathrm{F}_{\text {tabel }}=3,968$. Berdasarkan hasil penelitian, dapat disimpulkan bahwa siswa dengan karakterisitik kemandirian belajar rendah strategi pembelajaran yang tepat adalah Ekspositori. Implikasinya adalah para guru harus memahami karakterisitik siswa dan mereka harus dilatih untuk mengetahui karakteristik siswa. Dengan demikian, disarankan untuk keberhasilanproses pembelajaran, para guru harus memperhatikan karakteristik belajar siswa dan menerapkan beberapa strategi pembelajaran yang sesuai dengan karakteristik siswa.
\end{abstract}

\section{Keyword: Hasil Belajar Ekonomi, Strategi Pembelajaran, Ekspositori, Kemandirian Belajar.}

\section{A. PENDAhuluan}

Pendidikan memegang peranan penting dalam upaya meningkatkan kualitas Undangundang Republik Indonesia Nomor 20 Tahun 2003 Tentang Sistem Pendidikan Nasional Bab II Pasal 3 (2003:5-6) sumber daya manusia (SDM) yang mendukung kemajuan bangsa dan negara. Dalam Undang-undang Republik Indonesia Nomor 20 Tahun 2003 Tentang Sistem Pendidikan Nasional Bab II Pasal 3 (2003:5-6) dinyatakan bahwa: Pendidikan Nasional bertujuan untuk mengembangkan potensi peserta didik agar menjadi manusia yang beriman 
dan bertaqwa kepadaTuhan Yang Maha Esa, berakhlak mulia, sehat, berilmu, cakap, kreatif, mandiri dan menjadi warga negara yang demokratis serta bertanggungjawab. Hal ini memberi makna bahwa pelaksanaan pendidikan nasional memiliki tujuan yang kompleks yaitu bertaqwa kepadaTuhan-Nya, pendidikan juga diharapkan mampu membentuk peserta didik menjadi sosok yang cakap terhadap ilmunya dan mandiri, demokratis dan bertanggungjawab.

Berkaitan dengan amanat Undang-Undang Sistem Pendidikan Nasional di atas, maka pemerintah melakukan perbaikan dan peningkatan mutu pendidikan, di antara beberapa kebijakan yang telah dilakukan antara lain peningkatan jumlah sekolah, melengkapi sarana pembelajaran dan sertifikasi tenaga pendidik dan kependidikan, Bantuan Operasional Sekolah (BOS) dan sebagainya.

Namun demikian masih terdapat hambatan-hambatan serta kekurangan, hal yang memprihatinkan yang dapat dilihat langsung adalah hasil belajar belum mencapai hasil yang diharapkan. Berdasarkan data awal yang peneliti peroleh dari Madrasah Aliyah Negeri (MAN) Kp. Teungoh Kota Langsa yang merupakan data pada tiga tahun terakhir khususnya bidang studi Ekonomi. Perolehan hasil belajar mata pelajaran Ekonomi yang belum memuaskan tersebut dapat dilihat dari berbagai faktor. Faktor dominan yang dapat dilihat adalah selama ini proses pembelajaran kurang mendukung pemahaman peserta didik, di samping itu terlalu banyaknya materi yang dipelajari pada mata pelajaran Ekonomi juga merupakan faktor yang mempengaruh perolehan hasil belajar.

Faktor lainnya adalah proses pembelajaran yang menekankan pada aspek hafalan yang berorientasi pada pencapaian materi ajar, hal ini terlihat dari kegiatan pembelajaran yang dominan dilakukan dengan kegiatan ceramah dan pembelajaran berpusat kepada guru. Hal ini didukung berdasarkan hasil pengamatan awal terhadap kegiatan pembelajaran Ekonomi yang dilakukan guru ditemukan bahwa kecenderungan guru mengajarkan Ekonomi dalam memberikan pemahaman terhadap konsep, selalu dilakukan melalui penyampaian melalui kegiatan ceramah.

Mencermati persoalan tersebut, maka diperlukan upaya untuk mengatasi persoalan perolehan hasil belajar Ekonomi siswa Madrasah Aliyah Negeri (MAN) Kp. Teungoh Kota Langsa, yang merupakan sekolah bercirikan Islam setingkat dengan sekolah menengah atas yang masih relatif rendah. Salah satu upaya untuk mengatasinya adalah meningkatkan kualitas pembelajaran dengan penerapan strategi pembelajaran yang lebih tepat dalam pelaksanaan pembelajaran mata pelajaran Ekonomi.

Dalam hal ini, strategi pembelajaran yang diterapkan dalam kegiatan pembelajaran berpusat pada peserta didik dan menitik beratkan pada keaktifan peserta didik dalam belajar. 
Oleh karena itu melalui pemilihan strategi pembelajaran yang tepat diharapkan peningkatan mutu pembelajaran dan hasil belajar Ekonomi dapat ditingkatkan. Strategi pembelajaran yang dikaji dalam penelitian ini adalah strategi pembelajaran ekspositori. Strategi pembelajaran ekspositori menekankan penyampaian informasi yang dilakukan guru, sehingga terdapat kecenderungan peserta didik hanya sebagai pendengar pasif dan pencatat saja dimana fungsi guru merupakansatu-satunya sumber belajar. Dalam kegiatan pembelajaran ekspositori terjadi penumpukan informasi yang disampaikan guru sehingga kondisi yang demikian membuat peserta didik jenuh dan berakibat kepada pencapaian hasil belajar yang kurang maksimal.

Faktor lain yang turut berperan dalam keberhasilan pencapaian hasil belajar adalah karakteristik peserta didik. Dalam hal ini, kajian penelitian memfokuskan pada karakterisk kemandirian belajar. Perbedaan kemandirian belajar yang melekat pada diri peserta didik berakibat pada perbedaan kemampuan peserta didik dalam menyerap materi ajar Ekonomi. Dalam hal ini peserta didik yang dengan kemandirian belajar tinggi akan memberikan dampak untuk berinisiatif, kemauan belajar kuat serta kesiapan belajar yang dapat di atas sendiri tanpa tergantung dengan orang lain. Berbeda halnya dengan peserta didikdengan tingkat kemandirian belajar rendah yang memiliki ketergantungan pada lingkungannya sangat tinggi.

Perbedaan karakteristik peserta didik pada aspek kemandirian belajar yaitu peserta didikdengan tingkat kemandirian belajar tinggi dan peserta didik dengan tingkat kemandirian belajar diduga akan memberikan pengaruh yang berbeda terhadap perolehan hasil belajar Ekonomi peserta didik. Hal ini disebabkan karakteristik peserta didikdengan tingkat kemandirian belajar tinggi selalu mengerjakan dengan sungguh-sungguh tugas yang diberikan guru, karena bagi peserta didik dengan kemandirian belajar tinggi, hal tersebut merupakan tantangan sedangkan peserta didik dengan tingkat kemandirian belajar rendah cenderung mengharapkan dan membutuhkan bantuan guru, orang tua dan masyarakat lain dalam menyelesaikan tugas yang dikerjakannya.

Pemilihan strategi pembelajaran yang tepat diperlukan dan harus disesuaikan dengan kemandirian belajar peserta didik, karena mempelajari materi Ekonomi yang cukup padat maka dituntut kemandirian peserta didik dalam belajar untuk mencari sumber belajar yang beragam. Oleh karena itu, kemandirian belajar peserta didik adalah salah satu komponen yang harus diperhatikan dengan seksama oleh guru dalam mengidentifikasi kemampuan yang dimiliki peserta didiknya yang akan membantu dalam menentukan materi, strategi, dan media yang tepat untuk digunakan. Hal ini perlu dilakukan agar pembelajaran yang disampaikan 
dapat menarik perhatian peserta didik dan setiap detik yang berlangsung dalam kegiatan pembelajaran yang dilakukan akan bermakna dan tidak membosankan bagi peserta didik.

1. Bagaimana hasil belajar Ekonomi peserta didik yang diajar dengan strategi pembelajaran ekspositori?

2. Apakah hasil belajar Ekonomi peserta didik dengan kemandirian belajar tinggi lebih tinggi dari pada hasil belajar Ekonomi peserta didik dengan kemandirian belajar rendah?

3. Apakah terdapat interaksi antara strategi pembelajaran dan kemandirian belajar terhadap hasil belajar Ekonomi?

Romizowski (1981:276) menjelaskan strategi pembelajaran merupakan suatu pendekatan menyeluruh dan garis aksi yang merupakan satu pilihan dalam metode pembelajaran. Wena (2009:21)menjelaskan strategi pembelajaran berarti cara dan seni untuk menggunakan semua sumber belajar dalam upaya membelajarkan siswa. Sebagai suatu cara, strategi dikembangkan dengan kaidah-kaidah tertentu sehingga membentuk suatu bidang pengetahuan, strategi pembelajaran dapat dipelajari dan kemudian diaplikasikan dalam kegiatan pembelajaran. Sebagai suatu seni, strategi pembelajaran kadang-kadang secara implisit dimiliki seseorang tanpa pernah belajar secara formal tentang ilmu strategi pembelajaran.

Dick, Carey \& Carey (2009:178-179) mengatakan bahwa strategi pembelajaran memuat lima komponen utama yaitu: (1) aktivitas pembelajaran pendahuluan, (2) penyampaian informasi, (3) partisipasi peserta didik, (4) penilaian, dan (5) kegiatan tindak lanjut. Suparman (2012:245) menjelaskan komponen utama dalam strategi pembelajaran yaitu: (1) urutan kegiatan instruksional, (2) garis besar isi instruksional dan (3) sistema pelunsuran yang terdiri dari metode instruksional, media, alat instruksional dan alokasi waktu.

Gulo (2008:11) menjelaskan bahwa dalam pembelajaran ekspositori, guru mengolah secara tuntas pesan/materi sebelum disampaikan di kelas sehingga peserta didik tinggal menerima saja. Hakekat mengajar menurut pandangan ini adalah menyampaikan ilmu pengetahuan kepada siswa yang ditempatkan sebagai objek yang menerima apa yang diberikan guru.

Biasanya guru menyampaikan informasi mengenai bahan pembelajaran dalam bentuk penjelasan dan penuturan lisan, yaitu dengan metode ceramah. Pembelajaran ekspositori menghendaki siswa dapat menangkap dan mengingat informasi yang telah diberikan guru, serta mengungkapkan kembali apa yang telah dimikinya menjadi respon yang ia berikan pada saat guru melontarkan pertanyaan. Di sini terjadi komunikasi satu arah, 
karena itu proses belajar siswa kurang optimal sebab terbatas pada mendengarkan mencatat apa yang disampaikan guru.

Sagala (2007:78) menjelaskan strategi pembelajaran ekspositori bertitik tolak dari pandangan bahwa tingkah laku kelas dan penyebaran pengetahuan dikontrol dan ditentukan oleh guru/pengajar. Hakekat mengajar menurut pandangan ini adalah menyampaikan ilmu pengetahuan kepada peserta didik, peserta didik dipandang sebagai objek yang menerima apa yang diberikan guru. Biasanya guru menyampaikan informasi mengenai bahan pengajaran dalam bentuk penjelasan dan penuturan secara lisan, yang dikenal dengan istilah kuliah, ceramah dan lecture.

Dalam hal ini, guru aktif memberikan penjelasan atau informasi pembelajaran secara terperinci tentang materi pembelajaran, peserta didik diharapkan dapat menangkap dan mengingat informasi yang telah diberikan guru, serta mengungkapkan kembali apa yang dimilikinya melalui respon yang diberikan pada saat guru bertanya dan dapat menyelesaikan tes/quis pada tahap akhir pelajaran berlangsung.

Berdasarkan penjelasan di atas dapat dilihat bahwa strategi ekspositori merupakan kegiatan pembelajaran yang menempatkan guru sebagai sumber utama dan tunggal. Kegiatan pembelajaran dalam strategi pembelajaran ekspositori berlangsung menggunakan guru sebagai satu-satunya sumber belajar dan sekaligus bertindak sebagai penyaji isi pelajaran, tidak menggunakan sumber lainnya, kecuali garis-garis besar, isi dan jadwal pelajaran yang disampaikan pada permulaan pembelajaran, beberapa transparansi, lembar kertas yang berisi gambar, bagan atau lainnya yang digunakan untuk sebagai latihan selama proses pembelajaran.

Kemandirian belajar terkait dengan cara sendiri peserta didik dalam belajar, sebagaimana dipaparkan oleh Slameto (1995:20) menjelaskan bahwa belajar yang sesuai dengan kecakapan sendiri, cara sendiri, dan sifat-sifat sendiri yang lain bermanfaat untuk pencapaian tujuan belajar. Berdasarkan pendapat ini dengan kemandirian belajar, peserta didik bertanggung jawab atas pembuatan keputusan yang berkaitan dengan proses belajarnya dan memiliki kemampuan untuk melaksanakan keputusan yang diambilnya sebagai suatu proses yang membantu peserta belajar untuk mengambil pengendalian yang lebih besar terhadap belajarnya.

Brookfiere yang dikutip oleh Pannen (1997:55) menjelaskan bahwa kemandirian belajar memberikan kesempatan kepada peserta didik untuk menentukan tujuan belajar, merencanakan proses belajar, menggunakan sumber belajar yang dipilihnya, membuat keputusan akademis dan melakukan kegiatan-kegiatan yang dipilihnya untuk mencapai 
bentuk dan tujuan belajar. Hal senada diungkapkan Haryono (1998:12) bahwa ciri utama kemandirian belajar adalah kesempatan yang diberikan kepada peserta didik untuk menentukan tujuan belajar, sumber belajar dan evaluasi belajarnya. Kemandirian belajar pada dasarnya merujuk pada sikap dan prilaku independensi peserta didik untuk melakukan aktivitas belajar yang datang dari diri sendiri tanpa tergantung kepada orang lain. Kemandirian belajar ditunjukkan melalui indikator sebagai berikut: (a) percaya terhadap kemampuan sendiri, (b) memiliki inisiatif, (c) melakukan sesuatu bukan karena orang lain, (d) menyelesaikan masalah tanpa tergantung kepada orang lain, dan (e) merasa puas dengan hasil kerja.

\section{B. KERANGKA BERPIKIR}

Pada pelaksanaan pembelajaran ekspositori, guru berperan sebagai penyampaian utama dari materi ajar Ekonomi dan lebih menekankan penyampaian informasi atau ceramah yang dilakukan guru, sehingga terdapat kecenderungan peserta didikhanya sebagai pendengar pasif dan pencatat saja dimana fungsi guru merupakan satu-satunya sumber belajar. Penyajian materi ajar yang disampaikan melalui dominasi ceramah secara langsung kepada peserta didik tanpa ada gambaran umum sehingga membuat daya serap belajar rendah. Peserta didik terkadang sulit memahami dan menghubungkan antara sub pokok bahasan yang baru diterimanya dengan sub pokok bahasan yang telah lalu. Terjadi penumpukan informasi yang disampaikan guru melalui ceramah sehingga kondisi yang demikian membuat peserta didik jenuh dan berakibat kepada pencapaian hasil belajar yang kurang maksimal.

Kemandirian belajar mempunyai makna bagi upaya peningkatan kemampuan dalam belajar sekaligus dalam kerangka mencapai hasil belajar yang diperolehnya. Peserta didik dengan tingkat kemandirian belajar tinggi ditandai dengan kecenderungan tidak bergantung pada orang lain, berinisiatif, motivasi belajar tinggi dan tidak mudah menyerah, sedangkan peserta didik dengan tingkat kemandirian rendah ditandai dengan kecenderungan; selalu bergantung pada orang lain, kurang inisiatif, motivasi belajar rendah, dan cepat menyerah.

peserta didikdengan karakteristik kemandirian belajar rendah lebih tepat diajar dengan strategi pembelajaran ekspositori. Hal ini disebabkan peserta didikyang memiliki kemandirian belajar tinggi lebih cenderung belajar secara mandiri dan mempunyai kemauan tinggi dalam meenyelesaikan tugas. Hal ini berbeda pada peserta didik dengan kemandirian belajar rendah yang cenderung selalu mendapat penjelasan dari guru atau teman sejawatnya. 


\section{METODE PENELITIAN}

Populasi penelitian ini adalah siswa MAN Kp. Teungoh kelas XI jurusan IPS. Setiap kelas dalam populasi memiliki karakteristik yang sama, artinya setiap kelas tidak memiliki peserta didik yang pernah tinggal kelas, peserta didik rata-rata memiliki umur yang tidak jauh berbeda secara siginifikan, menggunakan kurikulum pendidikan yang sama. Di samping itu pembagian kelas tidak dilakukan berdasarkan rangking, sehingga tidak terdapat kelas unggulan yang karakteristik peserta didiknya berbeda.

Penelitian ini menggunakan metode eksperimen dengan rancangan quasi eksperimen disain faktorial $2 \times 2$. Alasan pemilihan rancangan quasi eksperimen adalah: (1) kelas yang dilaksanakan pembelajaran sudah terbentuk sebelum, dan (2) karakteristik peserta didik yang dikontrol hanya satu aspek yaitu kemandirian belajar. Melalui disain penelitian dibandingkan pengaruh strategi pembelajaran ekspositori terhadap hasil belajar Ekonomi ditinjau dari siswa. Strategi pembelajaran ekspositori sebagai variabel bebas, kemandirian belajar sebagai variabel moderator dan perolehan hasil belajar dalam mata pelajaran Ekonomi sebagai variabel terikat.

Sebelum dilakukan pelaksanaan pembelajaran terlebih dahulu ditinjau faktor-faktor kesamaan dari kedua kelas yaitu kesamaan dalam faktor-faktor yang mempengaruhi pelaksanaan kegiatan pembelajaran. Hal ini dilakukan dengan maksud untuk meyakinkan kedua kelompok kelas mempunyai karakteristik yang dianggap sama, kecuali faktor perlakuan strategi pembelajaran. Faktor-faktor yang dapat mempengaruhi kegiatan pembelajaran antara lain faktor tujuan pembelajaran, guru, situasi, kondisi kelas dan media.

strategi pembelajaran ekspositori dilakukan dengan menerapkan langkah-langkah sebagai berikut:

1. Persiapan. Guru menyiapkan peserta didik untuk menerima pelajaran dengan menyampaikan tujuan pembelajaran dan membangkitkan motivasi dan minat, merangsang rasa ingin tahu dan menciptakan suasana yang menyenangkan.

2. Penyajian. Guru menyajikan materi dengan memperhatikan penggunaan bahasa, intonasi suara, menjaga kontak mata dengan peserta didik, menggunakan cara-cara yang menyegarkan.

3. Korelasi. Guru menghubungkan materi ajar dengan pengalaman peserta didik atau hal yang lain yang memungkinkan siswa dapat menangkap keterkaitannya dalam struktur pengetahuan yang dimilikinya. Langkah ini dilakukan untuk memberikan makna terhadap materi ajar. 
4. Menyimpulkan. Guru memberikan pemahaman kepada peserta didik tentang materi yang diajarkan dengan memberikan kesimpulan dan memberikan keyakinan kepada peserta didik tentang kebenaran dengan demikian peserta didik tidak ragu akan penjelasan materi ajar yang disampaikan guru.

5. Aplikasi. Guru memberikan tes kepada peserta didik untuk mengukur dan mengetahui tingkat pemahaman peserta didik terhadap materi ajar.

Teknik pengumpulan data yang digunakan adalah teknik tes dan teknik non tes. Tes digunakan untuk menjaring data hasil belajar Ekonomi, sedangkan teknik non tes yaitu angket digunakan untuk menjaring data kemandirian belajar. Instrumen penelitian tes hasil belajar yang digunakan adalah bentuk tes pilihan berganda (multiple choice) dengan empat alternatif jawaban. Instrumen penelitian kemandirian belajar disusun dalam bentuk kuesioner dengan menggunakan skala Likert.

Variabel kemandirian belajar peserta didik dengan indikator-indikatornya : (1) percaya terhadap kemampuan sendiri, (2) memiliki inisiatif, (3) melakukan sesuatu bukan karena orang lain, (4) menyelesaikan masalah tanpa tergantung kepada orang lain dan (5) merasa puas dengan hasil pekerjaan sendiri. Indikator tersebut disarikan dari teori-teori mengenai kemandirian.

\section{HASIL PEMBAHASAN}

Data yang dideskripsikan pada penelitian ini adalah data hasil belajar Ekonomi pada kelas pembelajaran ekspositori. Rincian pemaparan deskripsi data meliputi: skor terendah, skor tertinggi, mean, modus, median, varians dan simpangan baku.

Data hasil belajar Ekonomi siswa yang diajar dengan strategi pembelajaran ekspositori diperoleh harga rata-rata mean $\left(\mathrm{X}^{-}\right)=26,92$; modus $=26,3$; median $=26,81$; varians $=15,02$; simpangan baku $=3,87$; skor tertinggi $=34$; dan skor terendah $=19$. Berdasarkan pada data hasil penelitian, dapat dijabarkan bahwa dengan mean 26,92 berada pada kelas interval 25 - 27, ini berarti ada sebesar 32,50\% siswa memiliki skor rata-rata kelas, 25,00\% siswa memiliki skor dibawah skor rata-rata kelas dan 42,50\% siswa memiliki skor diatas skor rata-rata kelas.

Berdasarkan perhitungan anava faktorial $2 \times 2$ diperoleh Fhitung $=7,18$, sedangkan nilai Ftabel $=3,96$ untuk dk $(1,76)$ dan taraf nyata $\alpha=0,05$. Ternyata nilai Fhitung $=7,18>$ Ftabel $=3,96$ sehingga pengujian hipotesis menolak Ho. Dengan demikian dapat ditarik kesimpulan bahwa terdapat interaksi antara strategi pembelajaran dan kemandirian belajar dalam memberikan pengaruh terhadap hasil belajar Ekonomi siswa teruji kebenarannya. 
Hasil penelitian ternyata menunjukkan semua hipotesis penelitian yaitu : (1) hasil belajar siswa yang diajar dengan strategi pembelajaran ekspositori adalah rendah, (2) Hasil belajar Ekonomi dari siswa dengan kemandirian belajar tinggi lebih tinggi daripada hasil belajar Ekonomi siswa dengan kemandirian belajar rendah, dan (3) Terdapat interaksi antara strategi pembelajaran dan kemandirian belajar memberikan pengaruh terhadap hasil belajar Ekonomi siswa, dapatlah diterima ketiga-tiganya.

Pertama, hasil yang diperoleh dari penelitian ini menunjukkan adanya pengaruh strategi pembelajaran terhadap hasil belajar siswa dalam bidang studi Ekonomi. Hal ini memberikan penjelasan dan penegasan bahwa strategi pembelajaran merupakan salah satu faktor yang menjadi perhatian untuk meningkatkan hasil belajar Ekonomi. Hal ini dapat dimaklumi karena melalui penerapan strategi pembelajaran yang tepat dapat meningkatkan partisipasi aktif siswa dalam pembelajaran yang pada gilirannya dapat menggiring keberhasilan dan ketercapaian tujuan pembelajaran itu sendiri. Dengan demikian konsekuensinya apabila strategi pembelajaran kurang tepat maka tentu akan berakibat berkurang pula partisipasi aktif siswa dalam pembelajaran. rata-rata hasil belajar Ekonomi pada kelompok siswa dengan kemandirian belajar rendah dan dibelajarkan

Kedua, hasil penelitian juga menunjukkan bahwa kemandirian belajar siswa berpengaruh terhadap hasil belajar Ekonomi. Siswa dengan kemandirian belajar tinggi mempunyai mempunyai hasil belajar Ekonomi lebih tinggi atau unggul dibandingkan dengan siswa dengan kemandirian belajar rendah. Pernyataan tersebut memberikan penjelasan dan penegasan bahwa kemandirian belajar signifikan memberikan pengaruh dalam meningkatkan hasil belajar Ekonomi siswa. Kemandirian belajar yang dipilah atas kemandirian belajar tinggi dan kemandiria belajar rendah ditentukan dari hasil skor hasil angket. Siswa dengan kemandirian belajar tinggi memiliki karakter dalam belajar selalu ingin menemukan jawaban. Dengan demikian konsekuensinya apabila siswa dengan kemandirian belajar tinggi tentu akan maksimal pula pencapaian hasil belajar Ekonomi, sebaliknya hal yang berbeda terjadi pada siswa dengan kemandirian belajar rendah tingkat pencapaian belajarnya kurang maksimal.

Perbedaan kemandirian belajar ini juga berimplikasi kepada guru di dalam melaksanakan pembelajaran di kelas. Tindakan yang dapat dilakukan guru adalah dengan menerapkan dan mengarahkan dengan membentuk kelompok belajar atau kelompok diskusi didalam kelas di mana siswa saling memberikan bantuan kepada siswa dengan kemandirian belajar rendah, dengan demikian kegiatan pembelajaran bagi siswa dengan kemandirian 
belajar rendah dapat terbantu dalam memahami materi pelajaran. dengan demikian kegiatan pembelajaran bagi siswa dengan kemandirian belajar rendah dapat terbantu dalam memahami materi pelajaran.

Ketiga, hasil penelitian juga menunjukkan terdapat interaksi strategi pembelajaran dan kemandirian belajar terhadap hasil belajar Ekonomi. siswa dengan kemandirian belajar tinggi yang diajar dengan menggunakan strategi pembelajaran ekspositori rata-rata mempunyai hasil belajar Ekonomi yang lebih rendah. Sedangkan bagi siswa dengan kemandirian belajar rendah secara rata-rata hasil belajar Ekonomi yang diajar dengan strategi pembelajaran ekspositori lebih tinggi. Dengan demikian dapat dipahami bahwa strategi pembelajaran ekspositori lebih tepat digunakan bagi siswa dengan karakteristik kemandirian belajar rendah.

Hasil penelitian juga menunjukkan bahwa untuk meningkatkan hasil belajar Ekonomi dipengaruhi oleh strategi pembelajaran yang diterapkan oleh guru dan kemandirian belajar yang dimiliki siswa. Dalam hal ini antara guru dan siswa mempunyai peranan yang sama dan berarti dalam meningkatkan hasil belajar Ekonomi itu sendiri, sehingga dengan demikian untuk mencapai hasil belajar yang maksimal maka kedua variabel tersebut yaitu strategi pembelajaran dan kemandirian belajar perlu menjadi perhatian sekaligus.

\section{E. DAFTAR PUSTAKA}

Dick, Walter, Carey, L. dan Carey, J.O. 2009. The Systematic Design of Instruction, Seventh Edition. New Jersey: Pearson.

Gulo, W. 2008. Strategi Belajar Mengajar. Jakarta: Grasindo.

Haryono, A. 1998. Strategi Pembelajaran. Jakarta: Dirjen Pendidikan dasar dan Menengah Departemen Pendidikan dan Kebudayaan.

Pannen, P. 1997. Belajar Mandiri, Jakarta: Dirjen Perguruan Tinggi Kemenetian Pedidikan dan Kebudayaan.

Romizowski, A.Z. 1981. Designing Instructional System. New York: Nichol Publishing Company.

Sagala, S. 2012. Konsep dan Makna Pembelajaran. Bandung: Alfabeta.

Slameto.1995.Belajar dan Faktor-Faktor Yang Mempengaruhinya, Jakarta: Rineka Cipta.

Wena, M. 2009. Strategi Pembelajaran Inovatif Kontemporer. Jakarta: Bumi Aksara. 